\title{
Factors Impacting Job Satisfaction of Employees in the Fast Food Industry in Cape Town
}

\author{
Nnenna E. Ukandu \\ Faculty of Business Cape Peninsula University of Technology, Cape Town South Africa \\ Wilfred I. Ukpere \\ Department of Industrial Psychology \& People Management, \\ Faculty of Management University of Johannesburg, \\ P. 0. Box, 524, Johannesburg, South Africa \\ Corresponding email: wiukpere@uj.ac.za or wilfredisiomaukpere@gmail.com
}

\section{Doi:10.5901/mjss.2014.v5n3p51}

\begin{abstract}
Job satisfaction increases the level of performance in any organisation including the fast food outlets. Job satisfaction helps to stimulate employees' commitment in the workplace. In other words, employee satisfaction is vital for organisational development and growth. The fast food workers are unique and have their individual needs, potentials, values and goals. Job satisfaction can also enhance the level of motivation in the workplace. Hence, when the workers are satisfied, they also tend to be motivated towards organisational goals. This paper aims to look at factors impacting the job satisfaction of employee within the fast food industry, in order to proffer ways of improving the level of job satisfaction of fast food employees, in order to achieve a high level of employee and organisational performance. A survey concentrated mainly on the fast food industry. Only fast food employees with at least six (6) months experience were selected for the study, in order to obtain a reliable and valid response. Data was obtained from both the operational workers, administration, cashiers and the managers. A total of 200 closed-ended questionnaires were distributed and 123 employees responded, which gave a response rate of $62.5 \%$. Research finding shows that the rate of personal growth of the employees in their workplace was not satisfactory with a rate of $56.1 \%$ respondents. Also, the flexible time plan was not very satisfactory to the workers since they were given a flexible time sometimes during busy periods. In addition, the employees were not allowed to participate in decisions that affects them. It is thus proposed that fast food employees should be empowered through effective participation in decision making. Moreover, the employee skills should be improved through coaching and feedback system.
\end{abstract}

Keywords: Job Satisfaction, Employee dissatisfaction, Employee Commitment, Working Conditions, Pay and benefits.

\section{Introduction}

Job satisfaction is the extent to which an employee is happy with his/her job. This can help to improve an employee's positive attitude towards work. Stone (2005:413) has stated that job satisfaction is the degree to which employees have positive attitudes towards their jobs. According to Locke (1976), cited in Fulford (2005:74), job satisfaction is a pleasurable or positive emotional state resulting from the appraisal of one's job or job experiences. As aforementioned, employee turnover in the fast food industry is at a record high due to job dissatisfaction. Absenteeism has also multiplied owing to work related stress, as jobs in the industry are monotonous and not often rotated to develop their skills and performance, could bring about ultimate job satisfaction (Ukpere, 2007: 461).Ivancevich (2007:12) interjected that there should be a feeling of the right job so that employees can be productive, since workers spend one-third of their day at work and, therefore, require a good working conditions, working environment and co-operative co-workers in order to be comfortable in the workplace (Charner \& Fraser, 2003:48). To keep employees satisfied, there must be for good remuneration, medical aid and fringe benefits in order to deliver good quality services. Workers satisfaction, almost tantamount to workers motivation. Employees tend to produce good quality work and good customer services when they are satisfied and motivated. Unsatisfied workers will result in high absenteeism, low quality outputs and high rate of employee turnover (Ivancevich, 2007:12). Poor satisfaction of worker may be as a result of poor working conditions, less fringe benefits, autocratic management style, and etcetera. Such vices have adverse implications on employee performance in the workplace, particularly in the fast food industry. Thus, job satisfaction has been recognised as an important factor in the fast food industry to ameliorate the negative attitudes of employees towards their job or 
organisation as far as absenteeism and turnover are concerned (Vallen, 1993, cited in Fulford, 2005: 74).

However, Job dissatisfaction is widespread among workers of all ages across all income brackets within the fast food industry (Jones \& Dawis, 1992:142). It has been observed that almost half of the workers in most fast food outlets are dissatisfied with their work. Job dissatisfaction is experienced when employees are not happy with their job, or when things are not the way they should be (Stone, 2005:416). This can occur as a result of poor pay, a poor working environment and bad working conditions. Carrell, Elbert, Hatfield, Grobler, Marx and Schyf (1999:575) states that excessive absenteeism, turnover and grievances often result when workers experience high levels of job dissatisfaction, which is quite present in most fast outlets. Currently, most employees in the fast food industry have complained of being overwork or work overloads with poor pays. They are normally required to work more than 40 hours per week as full-time workers, while part-time workers work more than 30 hours per week. This over-time work is often not properly remunerated in accordance with the Basic Condition of Employment.

\section{Problem Statement}

Fast food employees spend substantial part of their salary on uniformed such as clothing and shoes. It has been observed that more than $38 \%$ of their time at work is spent doing other things that are not part of their job description such as washing of plates, cleaning the floor and toilet, emptying of refuse bins, etc. In addition to that, it has been estimated that over 36\% of workers in the fast food industry work during weekend shifts (Dawson, 2007:1). Generally, workers do not have enough time to rest at home or visit friends. In fact, there is no time to make new friends and meet new people. A total of $6 \%$ of employees maintained that their sex lives have been adversely affected (Dent, 2007:1). Some workers claim that their jobs are not challenging and lacks career progression. More than that, poor salaries and less benefits such as paid holiday leaves were also issues for almost 25\% of the workers (Dent, 2007:1). Fast food jobs indeed have adverse effect on the lives of most employees due to the nature of the working environment, which has exacerbated the level of stress and stress related illnesses, which negatively impacts job satisfaction.

\section{Research Questions}

The above statement led to the following research question:

- What are the factors impacting the job satisfaction of employees in the fast food industry,

- What is the relevance of job satisfaction in the management of employees in the fast food outlets,

- What are the possible ways of improving the level of job satisfaction and employee performance in the in fast food industry.

\section{Research Objectives}

The objectives of this paper are:

- To establish factors impacting the job satisfaction of employee within the fast food industry,

- To establish the relevance of job satisfaction in the management of employees in the fast food outlets,

- To proffer ways of improving the level of job satisfaction and employee performance in the in fast food industry.

\section{Literature Review}

Some authorities have given reasons why workers feel the way they do in the workplace. Discrepancy theory states that a person's job satisfaction comes from what the person feels as important rather than fulfilling his/her needs. This theory also suggests that dissatisfaction will only occur when a person receives less than what he/she expects (Berry, 1997). However, Herzberg's theory is one of the most significant theories of motivation and job satisfaction

\subsection{Herzberg's Theory}

Herzberg investigated the question: "what do people want from their jobs?" (Swanepoel et al., 2003:32). There are different variables that can make people feel either good or bad about their jobs. These factors were indicated by Herzberg as intrinsic and extrinsic factors, which is where the name two factors theories originated from. The intrinsic 
factors include advancement, recognition, responsibility and achievement, while the extrinsic factors comprise of status, security, company policy, administration, remuneration, supervision, and interpersonal relations, which are referred to by Herzberg as "hygiene" factors. These latter factors do not motivate employees, although they should be present in the workplace to placard them. Employees are motivated by internal values rather than external values. Hence, motivation should be internally generated through those intrinsic factors, which are known as "motivators".

Swanepoel et al. (2003:329) remark that job satisfaction is a function of challenging, stimulating activities or work content called the variable of motivators, while job dissatisfaction is a function of the job context called the hygiene factors. Herzberg believed that the opposite of "satisfaction" is "no satisfaction", and the opposite of "dissatisfaction" is "no dissatisfaction" and, therefore, by removing the dissatisfiers from a job will not make the job satisfying (Robbins \& Judge, 2009:211). Managers who seek to remove those factors that lead to job dissatisfaction may bring about peace, but not motivation. Hence, instead of motivating their own workforce, may end up placating them. Herzberg (2003 cited in Poulston, 2009: 25) suggested pay and working conditions as part of the hygiene factors that could nullify the motivating effects of satisfiers such as promotion, prospects, recognition, and personal growth". Therefore, fast food outlets should not rely only on monetary incentives in terms of satisfying their employees, since money alone will not improve employees' satisfaction and up performance. Therefore, there is a need to complement intrinsic with extrinsic motivation elements, in order to achieve organizational effectiveness and employee commitment.

\subsection{Employee turnover and organizational commitment}

Within the fast food industry, the attitudes of employees influence their intentions to behave in a certain ways, and those intentions in turn, influence their general behaviour (Fishbein \& Ajzen, 1975, cited in Fulford, 2005:74). One behavioural manifestation of an employee's attitude towards his/her job is employee turnover. Employee turnover in the fast food industry is approximately 104\% (Berta, 2003). The cost of replacing an employee has been estimated at R35, 000 a year (depending on the service level) (Simons \& Hinkin, 2001). Thus almost R8.4 million is spent on hiring and training workers in a year (Fulford, 2005:74). Apart from employee turnover, organizational commitment is another important issue to consider.

Organisational commitment is the psychological attachment that an employee has to an organisation (O'Reilly \& Chatman, 1986, cited in fulford, 2005: 74). This measures the degree to which an employee identifies with or adopts the values or perspectives of the organisation in which he/she works (Fulford, 2005:75). Organisational commitment measures attachment or loyalty to the entire organisation, while job satisfaction measures employee fulfilment within a specific job. Organisational commitment is positively related to performance and effectiveness and negatively related to turnover and absenteeism (Larson \& Fukami, 1984, cited in Fulford, 2005:75). Job satisfaction in turn is a direct fundamental sign of organisational commitment (Williams \& Hazer, 1986 cited in Fulford, 2005: 75). Most Fast food organisations do not allowed their employees participate or join in labour unions. Unions are supposed to help workers in resolving their internal and external problems, whilst assisting them in during collective bargaining (Ukpere, 2007: 462).

When employees in the fast food industry are not satisfied with their jobs, their performance levels will drop and they will not be committed to the organisation in which they work. Employees are unique, which is why each employee has his/her individual needs, potential, values, strengthening history, attitudes and goals.

\subsection{Working conditions}

Fast food workers need enough resources such as time, money and equipment to be able to do their work effectively. However, resources are scarce, which means that decisions should be made to distribute them fairly. The needs and goals of the industry should be prioritized. The physical layout of the work environment such as neatness, organisation, convenience, attractiveness and stimulus (noise, air, hazards and so on) should not threaten the well-being of employees (Nel, et al., 2004: 21).

Reiter (1986, cited in Royle \& Towers, 2002:44) states that public humiliation, unsafe working conditions and total lack of respect and dignity are amongst reasons why fast food employees are not happy. Most jobs in most fast food outlets have reflected abusive and poor working conditions, poor remuneration, long working hours and lack of participation in decision making of the organisation, especially in areas that concern workers (Ukpere, 2007: 460). Almost all the aspects of fast food work are highly standardized and rigorously monitored (Royle, 2004:61). Their methods of work produce identical products and their standards and productivity are broken down into the smallest steps. Work in the fast food industry is computerised, which reduces work movements and hence speed up production. Employees' 
skills are depleted and their work becomes an appendage of the machinery. For instance, lights and buzzers tell workers when to fry or bake. Furthermore, workers are expected to do a routinized job with no previous experience and training within a day (Royle, 2004:61-62).

The above could explain the reason why employees in the fast food industry always transit to other jobs in other sectors (Aquino, Griffeth, Allen, \& Hom, 1997, cited in Thoms, Wolper, Scott, \& Jones, 2004: 564). This is due to the poor earnings and working conditions in the industry. He further stated that their hours of work are long, shifts unpredictable, and promotions are very rare. There are times when workers want to join a union to negotiate with the company in which they work, but are not allowed to do so because the fast food industry works under a policy that is anti-union, which means that most of them do not often permit their employees to join unions. Any employee who violate this rule may be sacked (Harikripahai, 2007:5). Another issue is that the workforce, consists of 75 percent of youths under the age of 21 years (ibid), which might encourage the industry evade the requirement to pay minimum wages. It is also an observation that employee in the fast food industry are not entitled to sick leave with pay.

\subsection{Pay and benefits}

Poor pay has been mentioned as one of the features of the fast food industry`s business plan (Schlosser, 1998:73). It has also been noted that fast food outlets rely on exploited immigrant workers (Reischman, 2003:3). According to Streeten (2001:45, cited in Ukpere, 2007: 414), outsourcing is a cause of the decline in the demand for wages of semiskilled and unskilled labour. This affects the living standard of workers as they find it difficult to carry their family with their meagre wages (Harikripahai Organisation, 2007:3-4). Instead of increasing the wages of employee, most fast food outlets prefer to hire cheaper and non-unionized employees (Schlosser, 2003: 76). It has been argued that the extreme standardization of work in the fast food industry justifies low wages and benefits (Leidner, 1993, cited in Royle \& Towers, 2002:18). Inexperience people who are able to do the work are easily recruited as they have no alternative option. This tendency leads to job dissatisfaction and high labour turnover, as since workers' needs cannot be satisfied with the remuneration they receive within the fast food sector (ibid).

Benefits is another aspect that is lacking within the fast food industry. Other organizations provide benefits such as medical insurance and paid leave to their workers, which is not visible the fast food industry. Also, the work and life balance of the employee is problematic, since they have irregular unpredictable work schedule (Harikripahai Organisation, 2007: 4).

\section{Research Methodology: Sample and Research Process}

The focus of this study is on the fast food outlets in Cape Town. The research methods used were a combination of the qualitative and quantitative methods, which is also referred to as triangulation. A total of 200 questionnaires were distributed to the 200 samples selected, out of which 123 of them responded. The selected sample composed of all the staff members that have at least six (6) months of work experience within the fast food industry, in order to enhance the reliability of information obtained. In addition, before the floating of the questionnaire, a pilot study was conducted with few staff members and managers of some fast food outlets, and some corrections were made before the questionnaires were distributed to the wider audience. This measure helped to enhance the reliability and validity of the instrument. In addition, an open-ended, semi-structured interviews were conducted on a face-to-face basis with senior and store managers of the different fast food outlets, in order to ascertain their various opinions regarding job satisfaction of employees. A high ethical standard was as well maintained as far as data collection was concerned.

\section{Data Analysis}

This section deals with the data analysis of how respondents responded to questions relating to general job satisfaction with the fast food industry. 
Table 1: I am satisfied with my pay rate

\begin{tabular}{|ll|l|c|c|c|}
\hline & & Frequency & Percent & Valid Percent & Cumulative Percent \\
\hline Valid & Strongly agree & 10 & 8.1 & 8.2 & 8.2 \\
& Agree & 23 & 18.7 & 18.9 & 27.0 \\
& Disagree & 60 & 48.8 & 49.2 & 76.2 \\
& Strongly disagree & 29 & 23.6 & 23.8 & 100.0 \\
& Total & 122 & 99.2 & 100.0 & \\
Missing & System & 1 & .8 & & \\
Total & & 100.0 & & \\
\hline
\end{tabular}

$(\mathrm{n}=123)$

The basis for the above question was to know if the workers were satisfied with their pay rate. A total of $8.1 \%$ of respondents strongly agreed that they are satisfied with their pay rate and $18.7 \%$ agreed, which totalled $26.8 \%$ (8.1\% plus $18.7 \%$ ). A total of $48.8 \%$ of respondents disagreed and $23.6 \%$ strongly disagreed, which totalled $72.4 \%$ (48.8\% plus $23.6 \%)$ who were not satisfied with their pay rate. The other $0.8 \%$ of respondents did not answer the question.

Table 2: The pay for overtime is satisfying

\begin{tabular}{|ll|c|c|c|c|}
\hline & & Frequency & Percent & Valid Percent & Cumulative Percent \\
\hline Valid & Strongly agree & 10 & 8.1 & 8.2 & 8.2 \\
& Agree & 29 & 23.6 & 23.8 & 32.0 \\
& Disagree & 44 & 35.8 & 36.1 & 68.0 \\
& Strongly disagree & 39 & 31.7 & 32.0 & 100.0 \\
& Total & 122 & 99.2 & 100.0 & \\
Missing & System & 1 & .8 & & \\
Total & 123 & 100.0 & & \\
\hline
\end{tabular}

The above table shows that $8.1 \%$ of respondents strongly agree that their overtime pay rate is satisfying and $23.6 \%$ of respondents agreed, which totalled $31.7 \%$ (8.1\% plus $23.6 \%$ ). A total of $35.8 \%$ of respondents disagreed and $31.7 \%$ of respondents strongly disagreed, totalling $67.5 \%$ (35.8\% plus $31.7 \%$ ) who disagreed that their overtime pay rate is satisfying. About $0.8 \%$ decided not to answer this question.

Table 3: The rate of my personal growth in my workplace is?

\begin{tabular}{|ll|c|c|c|c|}
\hline & Frequency & Percent & Valid Percent & Cumulative Percent \\
\hline Valid & Highly satisfying & 10 & 8.1 & 8.3 & 8.3 \\
& Satisfying & 24 & 19.5 & 20.0 & 28.3 \\
& Neutral & 17 & 13.8 & 14.2 & 42.5 \\
& Not very satisfying & 31 & 25.2 & 25.8 & 68.3 \\
& Not satisfying at all & 38 & 30.9 & 31.7 & 100.0 \\
& Total & 120 & 97.6 & 100.0 & \\
Missing & System & 3 & 2.4 & & \\
Total & & 123 & 100.0 & & \\
\hline
\end{tabular}

$(n=123)$

Table 3 shows that from a total of 123 respondents, $8.1 \%$ stated that they are highly satisfied, which means that they are highly satisfied with the rate of personal growth in their workplace and $19.5 \%$ are satisfied, totalling $27.6 \%$ (8.1\% plus $19.5 \%$ ). A total of $13.8 \%$ are neutral and $25.2 \%$ are not very satisfied, while $30.9 \%$ said that they are not satisfied at all, which totals $56.1 \%$ (25.2\% plus $30.9 \%)$. A total of $2.4 \%$ of respondents did not comment on this question. 
Table 4: Do employees have freedom to make input with regard to objectives and standards?

\begin{tabular}{|ll|c|c|c|c|}
\hline & & Frequency & Percent & Valid Percent & Cumulative Percent \\
\hline Valid & Yes & 35 & 28.5 & 29.2 & 29.2 \\
& No & 85 & 69.1 & 70.8 & 100.0 \\
& Total & 120 & 97.6 & 100.0 & \\
Missing & System & 3 & 2.4 & & \\
Total & & 123 & 100.0 & & \\
\hline
\end{tabular}

$(n=123)$

In table 4 , a total of $28.5 \%$ of respondents stated that they have freedom to make input with regard to objectives and standards, while $69.1 \%$ said that they do not have freedom to make input with regard to the company's objectives and standards, and $2.4 \%$ of respondents did not answer the question

Table 5: Is your job execution made challenging by your supervisors?

\begin{tabular}{|ll|c|c|c|c|}
\hline & & Frequency & Percent & Valid Percent & Cumulative Percent \\
\hline Valid & Yes & 42 & 34.1 & 35.6 & 35.6 \\
& No & 76 & 61.8 & 64.4 & 100.0 \\
& Total & 118 & 95.9 & 100.0 & \\
Missing & System & 5 & 4.1 & & \\
Total & & 123 & 100.0 & & \\
\hline
\end{tabular}

$(n=123)$

In table 5 , a total of $34.1 \%$ of respondents said that their job execution is made challenging by their supervisors, while $61.8 \%$ said that their job execution is not made challenging by their supervisors, while $4.1 \%$ of respondents did not answer the question.

Table 6: Do you normally experience stress at your workplace?

\begin{tabular}{|cl|c|c|c|c|}
\hline & Frequency & Percent & Valid Percent & Cumulative Percent \\
\hline Valid & Yes & 106 & 86 & 86 & 86 \\
& No & 17 & 14 & 14 & 100.0 \\
& Total & 123 & 100.0 & 100.0 & \\
\hline
\end{tabular}

$(\mathrm{n}=123)$

In table 6 , a total of $86.2 \%$ of respondents said that they normally experience stress with their work, while $13.8 \%$ responded that they do not experience stress along with their work. This shows that a majority of fast food workers experience stress along with their work.

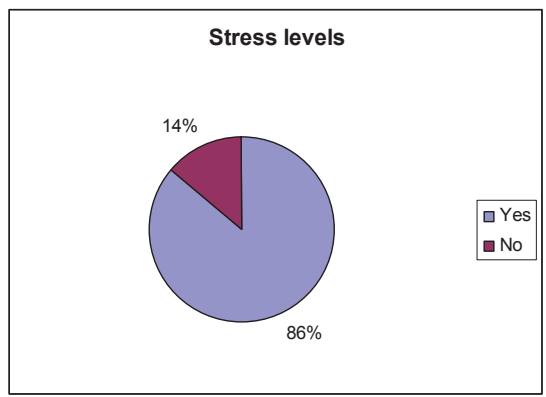

Fig. 1: Pie Chart of employee stress levels ( $n=123$ ) 
Table 7: What is your level of satisfaction concerning the physical environment of your workplace?

\begin{tabular}{|ll|c|c|c|c|}
\hline & Frequency & Percent & Valid Percent & Cumulative Percent \\
\hline Valid & Highly satisfying & 8 & 6.5 & 6.6 & 6.6 \\
& Satisfying & 33 & 26.8 & 27.3 & 33.9 \\
& Neutral & 29 & 23.6 & 24.0 & 57.9 \\
& Not very satisfying & 31 & 25.2 & 25.6 & 83.5 \\
& Not satisfying at all & 20 & 16.3 & 16.5 & 100.0 \\
& Total & 121 & 98.4 & 100.0 & \\
Missing & System & 2 & 1.6 & & \\
Total & 123 & 100.0 & & \\
\hline
\end{tabular}

$(n=123)$

Table 7 above shows that from a total of 123 respondents, $6.5 \%$ are highly satisfied with their physical environment, and $26.8 \%$ responded satisfactorily, totalling $33.3 \%$ (6.5\% plus $26.8 \%$ ). $23.6 \%$ were neutral and $25.2 \%$ are not very satisfied, while $16.3 \%$ said that they are not satisfied at all, totalling $41.5 \%$ (25.2\% plus $16.3 \%)$. A total of $1.6 \%$ did not answer the question.

Table 8: Feedback received from supervisors in my workplace is?

\begin{tabular}{|ll|c|c|c|c|}
\hline & Frequency & Percent & Valid Percent & Cumulative Percent \\
\hline Valid & Highly satisfying & 5 & 4.1 & 4.1 & 4.1 \\
& Satisfying & 25 & 20.3 & 20.5 & 24.6 \\
& Neutral & 27 & 22.0 & 22.1 & 46.7 \\
& Not very satisfying & 42 & 34.1 & 34.4 & 81.1 \\
& Not satisfying at all & 23 & 18.7 & 18.9 & 100.0 \\
& Total & 122 & 99.2 & 100.0 & \\
Missing & System & 1 & .8 & & \\
Total & 123 & 100.0 & & \\
\hline
\end{tabular}

$(n=123)$

Results in table above reveals that from a total of 123 respondents, $4.1 \%$ said that they are highly satisfied with the feedback received from their supervisors in their workplace, and $20.3 \%$ respondents said that they were satisfied, which totals $24.4 \%$ (4.1\% plus $20.3 \%$ ). However, $22.0 \%$ are neutral and $34.1 \%$ said that they are not very satisfied, while $18.7 \%$ said that they are not satisfied at all. A total of $0.8 \%$ of respondents did not answer the question.

\section{Discussion of Findings}

This section discusses the findings that emanates from the data analysis and corroborate it with literatures

\subsection{Pay}

Findings from the data analysis reveals that many fast food workers are not satisfied with their pay. Table 1 of the data analysis shows a negative response rate of $72.4 \%$ (48.8\% plus $23.6 \%)$ of respondents who stated that they were not satisfied with their pay rate. Similar negative response was revealed in Table 2, which that $67.5 \%$ of respondents disagreed that they were satisfied with overtime pay rate. The follow up interview harmonises with the information from the data analysis, as some interviewees opined that the average pay to them was not enough to make a living in terms of supporting their families. They emphasise that they are paid meagre amount in spite of the huge workload assigned to them. This is in line with the finding of Harikripahai Organisation (2007), which observed that fast food employees were poorly treated especially in the area of pay, which affects their capacity to care of their families. This could explain the reason why there is a high attrition rate within the industry, as dissatisfied talented employees seek job in other field. 


\subsection{Working conditions and environment}

Interviews reveal that a majority of fast food employees perform their duties in poor working conditions as the layout of their workplace is nothing to write home about. They posited that the poor state of hygiene seems not to be a major concern to managers. In the midst of the poor state of hygiene factors, employees are expected to effectively carry out their jobs. Moreover, the finding reveals that there is no flexible working time, which adversely affects the leisure and family time of fast food workers. Some employees also maintain that conflict are endemic in the organisation due to ineffective communication. Some interviewees have also mentioned that they are not given opportunities to participate in decisions that affects them. This was also reflected in Table 3, which shows that the rate of personal growth among staff members was not impressive. A total of $56.1 \%$ (25.2\% plus $30.9 \%$ ) of respondents noted that they were not satisfied with the rate of personal growth in their workplace. Also, $70.7 \%$ (34.1\% plus $36.6 \%)$ of respondents stated that they were not satisfied with overtime duty at their workplace. This was in line with literatures which confirmed that fast food employees are not satisfied with their working conditions and environment (Reiter 1986, cited in Royle \& Towers, 2002:44). It is important to note that unpleasant working conditions and environment result in poor performances and job dissatisfaction.

\subsection{Job characteristics}

With regard to job characteristics, interviewees complained that their work is less challenging and lack skill variety. Employees are also not given the freedom to execute their responsibility without the interference of the supervisors. Hence, several respondents indicated that they were not satisfied with decision making practices in their organisation. They added that they were not given freedom to provide input with regard to the organization's objectives and standards. These types of job characteristics mentioned above can result in job dissatisfaction. It could also result in workers feeling of apathy towards the organisation and the loss of a sense of belonging by workers. Furthermore, some interviewees maintained that stress, which is a result of work overload and meagre pay, is a major problem of the organisation.

The data analysis, as illustrated in Table 4, indicates that $69.1 \%$ of respondents have not been given the freedom to provide input with regard to the organization's objectives and standards. Table 5 showed that $61.8 \%$ of respondents stated that their job execution is not made challenging by their supervisors, and $86.2 \%$ of respondents in Table 6 indicated that their work stress levels are high. These comments supports the views of some fast food workers who claim that their jobs are not challenging due to a lack of career progression. Literatures have acknowledge that fast food jobs have negatively affected the life of most employees as many of them fall sick as a result of work overload and job stress (Stone, 2005:416; Ivancevich, 2007), which affects employee motivation.

\subsection{Satisfaction}

The finding reveals that employees are not very satisfied with their jobs. It was observed that the work environments of fast food outlets were not attractive, which ultimately affects the overall output of workers. Additionally, some interviewees stated that their work is not at all challenging. Findings from the interviews reveals that a majority of workers are not satisfied with their job. Table 7 showed that many employees were not satisfied with the physical environment of their workplace. Table 8 also showed that employees are not satisfied with the feedback from their supervisors. It is important to note that employees' job satisfaction will result in employee motivation and a happy workforce. Some workers posited that if workers are happy, customers will as well be happy.

\section{Recommendations and Conclusions}

Base on the findings of the research, it is recommended first and foremost that Managements of fast food outlets should endeavour to be awarding certain percentage of the organization's profit to their workers through a financial incentivebased compensation method. There is a need to share the company's pre-tax profits with employees depending on their basic salary. They should also define rules that guide this program to all participants and proper communication should be maintained to enable workers to become aware of implications and thus understand what is expected of them. They should set objectives that are challenging and attainable for employees. This will enable employees to track their performances in order to measure the overall success of the organisation. Both monetary and non-monetary rewards should be used as an incentive to motivate performance. Monetary rewards in the form of cash will help to stimulate the 
extrinsic motivation of worker, while non- monetary rewards such as training, health savings account, recognition etc., will go a long way to stimulating their intrinsic motivation and improve their overall job satisfaction.

More than that, managers should innovate ways of empowering their workers. It is imperative to mention that empowered employees always try to put in their best. Empowered employees are also very loyal to their employers, which enhances the relationship at work. It is imperative to empower employees by respecting and having a high regard for them, and acknowledging the fact that they are the reason for the organisation's success. Fast food workers should be empowered in different ways, for instance, they should be given opportunities to share their views during any decision making process. Moreover, their suggestions should not be taken for granted, but should be used to solve problems in the organisation. The management should be able to communicate with their workers in a clear and understandable terms. Managers should be able to know the abilities of their employees and assign them tasks that will allow them to enjoy the freedom of doing their work. Fast food employees' skills should be developed through a coaching and feedback system. A good degree of autonomy should indeed be given to fast food workers. In other words, they should be permitted to give their opinions on how a particular job should be performed. Substantial freedom, independence, and discretion to schedule work and determine procedures to be taken to execute their task, will increase the levels of employees' motivation. Greater autonomy will give workers a sense of accomplishment in the workplace, as they begin to take charge of directing their jobs. Contrary to popular belief, workers also enjoy taking responsibilities, especially when they are asked to stand in for their managers, in cases of absenteeism. This has an accelerator effect on workers' motivation, as they anticipate becoming managers someday.

Finally, the managements at fast food outlets should scrutinize employees ' compensation structure in order to improve the pay and reward system of employees. Employees' pay and benefits should be commensurate with their contributions. Health insurance plan, vacation, sick leave, retirement plan, holiday and overtime pay should not be relegated to the background, in order to keep workers motivated. Fast food employees should be rewarded for their efforts in the organisation's success. This will encourage them to give their best towards future organisational endeavours. Good pay and benefits will help to boost levels of motivation and staff retention. Managements at fast food outlets should implement fair compensation practices according to the ordinances of the International Labour Standard, which addresses issues relating to minimum wage and overtime pay. The emphasis here is that equal pay should be given for equal to both male and female workers irrespective of their race, colour or orientation. Managers should make sure that salary/wages that are paid to workers can accurately reflect the value of 'work done. They should consider the salaries paid to workers in other organizations similar to them as a benchmark. Managers should as much as possible be transparent with their compensation policies. This will protect workers from exploitation, as well as help to motivate and retain good and reliable employees within the fast food industry.

\section{References}

Aquino, K.G., Kallen, D.G and Hom, P.W. 1997. Integrating justice constructs into the turnover process: A test of a referent cognitions model. Academy of Management Journal, 40, 1208-1227.

Berry, Lilly M. (1997). Psychology at Work. San Francisco: McGraw Hill Companies Inc.

Berta, D. 2003. Yorgo Koutsogiorgas keeps Maggiano`s turnover down with upbeat culture. Nation's Restaurant News. (Online) Available: http://findarticles.com/p/articles/mi_m3190/is_32_37/ai_106586066 [23 May 2011].

Carrell, M.R.; Elbert, N.F.; Hatfield, R.D.; Grobler, P.A.; Marx, M. \& Schyf, S.Van der. 1999. Human Resource Management in South Africa. New Jersey: Prentice-Hall. Cengage Learning Business Press.

Charner, I and Fraser, B.S. 2003. Fast food jobs. National Study of fast food Employment. Washington DC: National Institute for Work and Learning Publishers.

Dawson, P. 2003. Reshaping Change. London: Routledge.

Dent, G. 2007. Alarmingly High levels of job Dissatisfaction in the United Kingdom. A research, commissioned by Learndirect Careers Advice. (Online) Available: http://www.femalefirst.co.uk/business/Alarmingly+High+Levels+of+Job+Dissatisfaction+in+the+UK393.html [18 May 2009].

Fishbein, M. and Azien, I. 1975. Belief, attitude, intention, and behaviour: An introduction to theory and research. Reading, PA: AddisonWesley.

Fulford, M. D. 2005. That's Not Fair. Journal of Human Resources in Hospitality and Tourism. 4 (1), 73-84.

Harikripahai Organization, 2007. The Fast Food Industry, McDonald's Market Research. (Online) Available: http://www.echeat.com /profile.php?mode=viewprofile\&u=harikripahai [20 March 2010].

Herzberg, F. 2003. One more time: How do you motivate employees? Harvard Business Review 81(1), 86-96.

Ivancevich, J.M. 2007. Human Resource Management. 10th ed. New York: McGraw-Hill.

Jones, L.K. and Dawis, R.V. 1992. Encyclopedia of Career Change and work issues. Pp.142-143. Phoenix: Oryx Press.

Larson, E.W. and Fukami, C.V. 1984. Relationships between worker behaviour and commitment to the organization and union. 
Proceedings of the Academy of Management, 222-226.

Leidner, R. 1993. Fast food, Fast Talk: Service Work and Routinisation of Everday Life. University of California Press, Berkeley: CA.

Locke, E.A. 1976. The nature and causes of job satisfaction. In M.D. Dunnette (Ed.), Handbook of Industrial and Organizational Psychology, pp. 1297-1349. Chicago: Rand McNally.

Nel, P.S., Van Dyk, P.S., Haasbroek, G.D., Schultz, H.B., Sono, T. and Werner, A. 2004. Human Resources Management. $6^{\text {th }}$ ed. Cape Town: Oxford University Press.

Poulston, J.M. 2009. Working Conditions in Hospitality: Employees`Views of the Dissatisfactory Hygiene Factors', Journal of Quality Assurance in Hospitality and Tourism. 10 (1), 23-43.

Reischman, S. 2003. Uncommon thought Journal: Fast food and Society. New York. (Online) Available: http://www.uncommonthought.com/mt32/cgi-bin/mt-popupemail.cgi?entry_id=4355 [10 March 2010].

Reiter, E. 1986. "Life in a fast - food factory". From on the job confronting the labour process in Canada Kingston and Moocreal. Canada: McGill Queen`s University Press.

Robbins, S.P. and Judge, T.A. 2009. Organizational behaviour. New York: Pearson.

Royle, T. 2004. Employment Practices of Multinationals in the Spanish and German Quick-Food Sectors: Low Road Convergence, European Journal of Industrial Relations 10(1), 51-71.

Royle, T. and Towers, B. 2002. Labour relations in the global fast food industry. London: Routledge Publishers.

Schlosser, E. 1998, Fast-Food Nation: The True Cost of American's Diet. National Magazine Award Winner. Rolling Stone Magazine, Issue 794. USA.

Schlosser, E. 2003. Fast food Nation. $2^{\text {nd }}$ ed. New York: Perennial/Harper Collins.

Simons, T. and Hinkin, T. 2001. The effect of employee turnover on hotel profits; a test across multiple hotels. Cornell Hotel and Restaurant Administration Quarterly. 42 (4), 65-69.

Stone, R.J. 2005. Human Resource Management. $5^{\text {th }}$ ed. Milton: John Wiley \& Sons.

Streeten, P. 2001. Globalisation: Threat or opportunity? Copenhagen: Copenhagen Business School.

Swanepoel, B.; Erasmus, B.; Van wyk, M. and Schenk, H. 2003. South African Human Resource Management: Theory \& Practice. $3^{\text {rd }}$ ed. Landsdowne: Juta.

Thoms, P.; Wolper, P.; Scott, K.S. and Jones, D. 2004. The Relationship between immediate turnover and employee Theft in the restaurant industry. Journal of Business and Psychology, 15 (4):5-11.

Ukpere, W.I. 2007. The functional relationship between globalization, Internationalisation, human resources and industrial democracy. CapeTown: Cape Peninsula University of Technology PhD Thesis.

Vallen, G.K. 1993. Organizational Climate and Burnout. The Cornell Hotel and Restaurant Administration Quaterly, 34 (1), 54-60.

Williams, L.J. and Hazer, J.T. 1986. Antecedents and consequences of satisfaction and commitment in turnover models: A reanalysis using latent variable structure equation methods. Journal of Applied Psychology. 71(2), 219-231. 